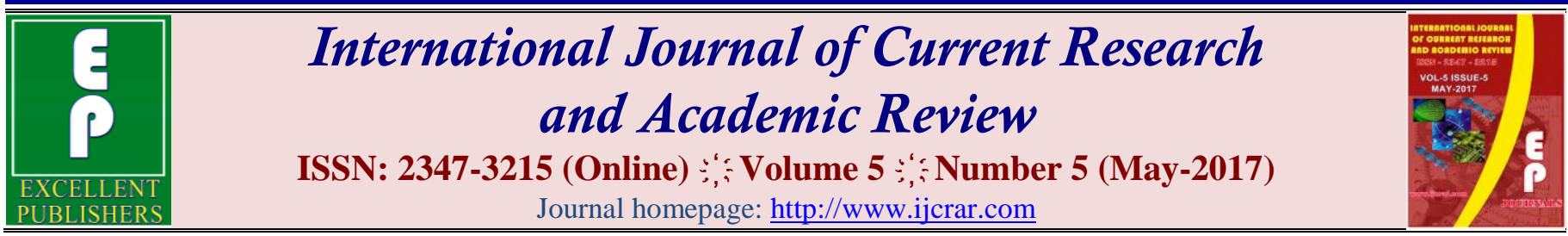

doi: https://doi.org/10.20546/ijcrar.2017.505.005

\title{
A Comparative Bacteriological and Molecular Study on Some Virulence Factor of Proteus spp Isolated from Clinical and Environment Specimens
}

\author{
Banaz M. Latif*, Salah. S. Zayn Aleabdyn and Ibraheem S. Ahmed
}

Iraq

*Corresponding author

\section{Abstract}

In this study, 300 clinical samples were collected from different hospitals in kirkuk city, 38 isolates of Proteus spp. were identified from urine, wounds, Ear swab, burns, stool and vaginal swab by using different bacteriological and biochemical tests. It was found that $26(68.4 \%)$ samples were identifies as Proteus mirabilis and $12(31.5 \%)$ samples were Proteus vulgaris. Among the 38 isolates of Proteus spp., 18 isolates $(47 \%)$ were isolated from urine samples; 2 (5.2\%) from wounds samples and $4(10.5 \%)$ isolates from burns samples: $10(26.3 \%)$ isolates from Ear swab; $3(7.8 \%)$ isolates from stool and 1 (2.6\%) isolates from vaginal swab. Out of 38 Proteus spp., 20 (52\%) were from female and $18(47 \%)$ from male at different age. Some important virulence factor to $P$. mirabilis isolates from patients was detected by using molecular techniques include PCR and it was found that all isolates gave positive result for ure $R$ gene at 225bp $11(100 \%)$ and 16s rRNA gene.
\end{abstract}

\section{Article Info}

Accepted: 05 May 2017

Available Online: 20 May 2017

\section{Keywords}

Proteus, PCR, virulence factors gene (ureR, 16srRNA).

\section{Introduction}

Proteus spp is Gram negative, facultative anaerobic, rod shaped bacteria. It has swarming motility, urease activity, do not usually ferment lactose. Since it belongs to the family of Enterobacteriaceae, general behaviors are applied on this genus: It is actively motile, non-spore forming, non-capsulated oxidase-negative, but catalase and nitrase positive. To identify Proteus spp, specific tests including positive urease and phenylalanine deaminase tests (Mordi and Momoh, 2009) and (Brooks et al., 2004) were used. Proteus is widely distributed in the natural environment. It can be found in polluted water and in soil and manure, where it plays an important role in decomposing organic matter of animal origin (Mordi and Momoh, 2009) and (Ro`zalski et al., 1997). The genus Proteus currently consists of five named species $(P$. mirabilis, $P$. penneri, $P$. vulgaris, $P$. myxofaciens and $P$. hauseri) and three unnamed genomospecies (Proteus genomo-species 4, 5, and 6), $P$. vulgaris, $P$. mirabilis and $P$. penneri are opportunistic human pathogens (Guentzel, 1996) and (O'hara et al., 2000).

P. mirabilis is often found as free-living organisms that are often found in soil, water, and the intestinal tract of many mammals, including humans. On (Brooks et al., 2004) and (Wassif et al., 1995 ) species level, indole is considered reliable, because it is positive for $P$. vulgaris but negative for $P$. mirabilis (Mordi and Momoh, 2009) and (Betty et al., 2007) P. mirabilis is the third most common (after E. coli and Klebsiella pneumoniae) cause of complicated UTI (causing 12\% of infections) and the second most common (after Providencia stuartii) cause 
of catheter-associated bacteriuria in the group of longterm catheterized patients (causing $15 \%$ of infections) (Wassif et al., 1995 ).

\section{Isolation and identification}

Through the period from September 2013 to March 2014, 300 clinical samples of urine, wounds, burns, ear swabs, stool and vaginal swabs were collected from patients. Samples were transferred to the lab for isolation and identification of Proteus spp. by using sterile equipment and media.

All samples were streaked on Blood agar, MacConkey agar. The plates were incubated aerobically at $37^{\circ} \mathrm{C}$ for 24 hours. The isolates were identified depending on the microscopical feature by using Gram stain to detect their response to stain, shape and arrangement (Prescott et al., 2002) and (Mac et al., 2000). In addition, the morphological features on culture media such as Swarming on blood agar, Non lactose fermented growth on MacConkey agar also several of biochemical tests were used to identify the Proteus isolates, such as catalase, oxidase tests, indole, methyl red/ VogesProskauer (MR-VP) test, citrate utilization tests, urea test, motility test, gelatin liquefaction test and triple sugar iron agar test (Betty et al., 2007). In addition to use API 20.

\section{Molecular detection of some virulence factors}

We using PCR technique for detection of some virulence gene include (16 SrRNA, ureR).

\section{Extraction of bacterial DNA}

This method was applied according to the genomic DNA purification kit that supplemented by the manufacturing company (Geneaid, UK). The suspension containing DNA was stored at $-20^{\circ} \mathrm{C}$ until used as template for PCR.

\section{PCR amplifications}

Detection of virulence genes was performed by amplifying the genes by PCR. Descriptions and sequences of the PCR primers used in this study are show in table 1.

\section{Antibiotic susceptibility test}

Kirby-Bauer method was done according to (Betty et al., 2007) to carry out antibiotic susceptibility test against 25 different antibiotics. A sterile cotton swab was submerged into bacterial suspension standardized to match the turbidity of the $0.5 \mathrm{McF}$ arland turbidity standard $\left(1.5 \times 10^{8} \mathrm{CFU} / \mathrm{ml}\right)$ by preparing serial dilutions of $18 \mathrm{hrs}$. Brain Heart Infusion culture of tested bacteria, third dilution was used after comparing it with the 0.5 McFarland turbidity standard.

The surface of Mueller Hinton agar plates were spread into four directions by the bacterial suspension, the plates were left for $10 \mathrm{~min}$. to dry. Then, the antibiotic disks were placed by sterile forces on the agar and pressed firmly to ensure the contact with the agar. The plates were incubated at $37^{\circ} \mathrm{C}$ for $18-24 \mathrm{hrs}$.

Inhibition zones developed around the antibiotic disks were measured by using a metric ruler in millimeters according to Clinical Laboratories Standards Institute (CLSI, 2011). The isolate was interpreted as susceptible, intermediate or resistant to a particular antibiotic by comparison with standard inhibition zones.

\section{Results and Discussion}

Out of 300 clinical specimens of different infection sources, 38 specimens $(12.6 \%)$ were isolated and identified as Proteus spp. These results agree with $\mathrm{Naz}$ and Rasool (2013) and Feglo et al., (2010) who mentioned that Proteus spp. from clinical specimens represented $(12.6 \%)$, and $(8.4 \%)$ respectively.

Twenty six specimens (68.4\%) of different clinical specimens were identified as Proteus mirabilis, and12 specimens $(31.5 \%)$ were identified as Proteus vulgaris as in figure 1 .

These results were agree with Feglo et al., (2010), that mentioned that the percentage isolation for Proteus mirabilis was (61\%), Proteus vulgaris was (30.5\%), but they showed that Proteus mirabilis are more widespread than Proteus vulgaris in clinical infections, because Proteus mirabilis is a part of normal flora of human beings and other mammalians that leads to contamination of water .

According to sex, out of 38 Proteus spp., 20 (52\%) were from female and $18(47 \%)$ from male at different age.

These results agreed with (Feglo et al., 2010), who mentioned that the percentage of isolation from female was $(57 \%)$ and from male was (43\%) but they not agree 
and showed (84.21\%) percentage of isolation and $(15.78 \%)$ isolation from males and females respectively. Among 38 isolates of Proteus spp., 18 isolates (47.3\%) isolated from urinary tract infections (UTI), Proteus mirabilis was (61\%), Proteus vulgaris was (38.8\%), These results agreed with Ahmed (2015), who mentioned that Proteus mirabilis and Proteus vulgaris was (66\%) $(30.3 \%)$ isolation from urinary tract infections (UTI). 2 (5.2\%) from wounds samples and $4(10.5 \%)$ isolates from burns samples: 10 (26.3\%) isolates from Ear swape Proteus mirabilis and Proteus vulgaris was (80\%) (20 $\%)$ These results agreed with (Al-duliami et al., 2011), who mentioned that Proteus mirabilis are more widespread than Proteus vulgaris in clinical infections. $3(7.8 \%)$ isolates from stool and 1(2.6\%) isolates from high cervical as in figure 2 and table 2.

Virulance factor of Proteus spp showin table 3.

Table.1 The primer sequence that used in present study

\begin{tabular}{|c|c|c|c|c|}
\hline $\begin{array}{c}\text { Gene } \\
\text { s } \\
\text { nam } \\
\text { e }\end{array}$ & Primer sequence (5-3) & $\begin{array}{c}\text { Siz } \\
\text { ep }\end{array}$ & Condition & $\begin{array}{c}\text { Referenc } \\
\text { e }\end{array}$ \\
\hline $\begin{array}{r}16 \mathrm{~s} \\
\mathrm{rRN} \\
\mathrm{A}\end{array}$ & $\begin{array}{l}\text { F } \\
\text { GGAAACGGTGGCTAATACCGCATAAT } \\
\text { GCAGCGCTAGGTGAGCCTAATGGG }\end{array}$ & $\begin{array}{l}101 \\
b p\end{array}$ & $\begin{array}{l}95^{\circ} \mathrm{C} 5 \mathrm{~min} \\
94^{\circ} \mathrm{C} \\
30 \mathrm{sec} \\
60^{\circ} \mathrm{C} 30 \text { se } \\
\mathrm{C} \\
72^{\circ} \mathrm{C} \\
10 \mathrm{sec} \\
72^{\circ} \mathrm{C} \\
10 \mathrm{~min}\end{array}$ & $\begin{array}{l}\text { Limanski1 } \\
\text { et } \quad \text { al. } \\
2005\end{array}$ \\
\hline ureR & $\begin{array}{cc}\mathrm{F} & \text { GGTGAGATTTGTATTAATGG } \\
\mathrm{R} & \text { ATAATCTGGAAGATGACGAG }\end{array}$ & $\begin{array}{l}225 \\
b p b\end{array}$ & $\begin{array}{l}94^{\circ} \mathrm{C} 4 \mathrm{~min} \\
94^{\circ} \mathrm{C} \\
40 \mathrm{sec} \\
58^{\circ} \mathrm{C} 1 \mathrm{~min} \\
72^{\circ} \mathrm{C} 20 \\
\sec \\
\quad 72^{\circ} \mathrm{C} \\
10 \mathrm{~min}\end{array}$ & $\begin{array}{l}\text { Zhang,W } \\
\text { et } \\
\text { al.,2013 }\end{array}$ \\
\hline
\end{tabular}

Table.2 Percentage of Proteus mirabilis isolates from different sources of infections

\begin{tabular}{|l|l|l|l|l|l|}
\hline sample & Proteus spp & P.mirabilis & Percentage\% & P.vulgaris & Percentage\% \\
\hline Urine & 18 & 11 & 61.11 & 7 & 38.88 \\
\hline Ear swpe & 10 & 8 & 80 & 2 & 20 \\
\hline Stool & 3 & 2 & 66.66 & 1 & 33.33 \\
\hline Wound & 2 & 1 & 50 & 1 & 50 \\
\hline Burns & 4 & 3 & 75 & 1 & 25 \\
\hline High cervical & 1 & 1 & 100 & 0 & 0 \\
\hline totale & 38 & 26 & $68.42 \%$ & 12 & $31.57 \%$ \\
\hline
\end{tabular}


Table.3 The number of Proteus spp isolates particular virulence factor

\begin{tabular}{|l|l|l|l|l|}
\hline $\begin{array}{l}\text { Virulence } \\
\text { Factors }\end{array}$ & No & Positive\% & No & Negative\% \\
\hline Urease & 38 & $100 \%$ & 0 & $0 \%$ \\
\hline Swarming & 38 & $100 \%$ & 0 & $0 \%$ \\
\hline $\begin{array}{l}\text { production } \\
\text { Agglutination of } \\
\text { RBCs }\end{array}$ & $71 \%$ & 11 & $29 \%$ \\
\hline Esterase Production & 31 & $81.5 \%$ & 7 & $18.4 \%$ \\
\hline $\begin{array}{l}\text { Protease } \\
\text { production }\end{array}$ & 34 & $89.4 \%$ & 4 & $10.5 \%$ \\
\hline Lipase production & 27 & $71 \%$ & 11 & $28.9 \%$ \\
\hline $\begin{array}{l}\beta-L a c t a m a s e \\
\text { production }\end{array}$ & 33 & $86.8 \%$ & 5 & $13 \%$ \\
\hline
\end{tabular}

Table.4 Antibiotics sensitivity of isolates of Proteus spp

\begin{tabular}{|r|l|l|l|l|}
\hline Antibiotic & con & Symble & No Sensitive & $\begin{array}{l}\text { \% Percentage } \\
\text { Sensitive }\end{array}$ \\
\hline Amikacin & $\mathbf{( 3 0 )}$ & AK & $\mathbf{3 0}$ & $78.94 \%$ \\
\hline Ampicillin & $\mathbf{( 1 0 )}$ & AM & $\mathbf{6}$ & $15.4 \%$ \\
\hline $\begin{array}{r}\text { Amoxicillin+clavulanic } \\
\text { acid }\end{array}$ & $\mathbf{( 3 0 )}$ & AMC & $\mathbf{4}$ & $10.52 \%$ \\
\hline Cefotaxim & $\mathbf{( 1 0 )}$ & CTX & $\mathbf{5}$ & $13.15 \%$ \\
\hline Ceftazidime & $\mathbf{( 1 0 )}$ & CAZ & $\mathbf{3}$ & $7.89 \%$ \\
\hline Ciprofloxacin & $\mathbf{( 1 0 )}$ & $\mathbf{C I P}$ & $\mathbf{3 7}$ & $97.36 \%$ \\
\hline Gentamicin & $\mathbf{( 1 0 )}$ & $\mathbf{C N}$ & $\mathbf{3 1}$ & $81.57 \%$ \\
\hline Tetracycline & $\mathbf{( 1 0 )}$ & TE & $\mathbf{1 5}$ & $39.47 \%$ \\
\hline Ceftrixon & $\mathbf{( 2 5 )}$ & $\mathbf{C R O}$ & $\mathbf{2 5}$ & $65.78 \%$ \\
\hline Nalidixic acid & $\mathbf{( 3 5 )}$ & $\mathbf{N}$ & $\mathbf{3 0}$ & $78.94 \%$ \\
\hline Amoxicillin & $\mathbf{( 1 0 )}$ & AX & $\mathbf{2 1}$ & $55.26 \%$ \\
\hline Co-trimoxazol & $\mathbf{( 1 2 5 / 3 3 . 7 5 )}$ & $\mathbf{S X T}$ & $\mathbf{2 0}$ & \\
\hline & & & & $52.36 \%$ \\
\hline & & & & \\
\hline & & & \\
\hline & & & \\
\hline & & & \\
\hline
\end{tabular}


Fig.1 Percentage of Proteus mirabilis and Proteus vulgaris isolation

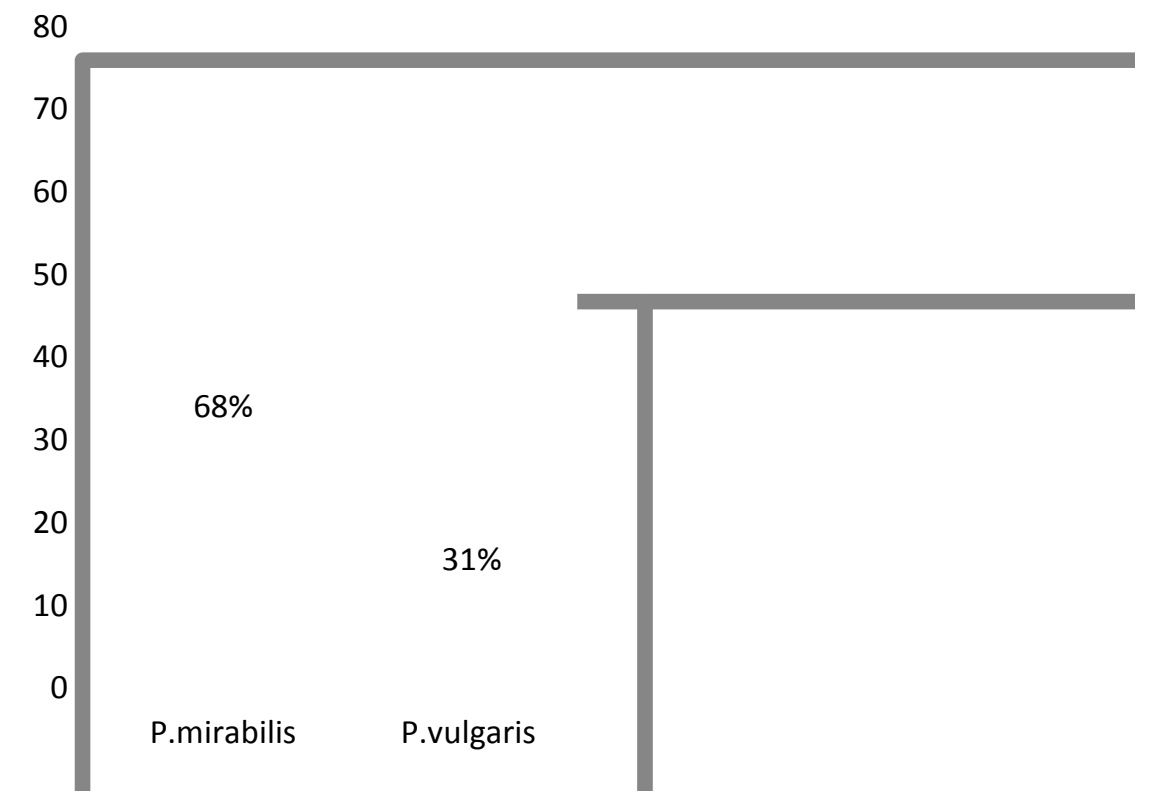

Fig.2 Percentage of Proteus mirabilis and isolates from different sources of infections

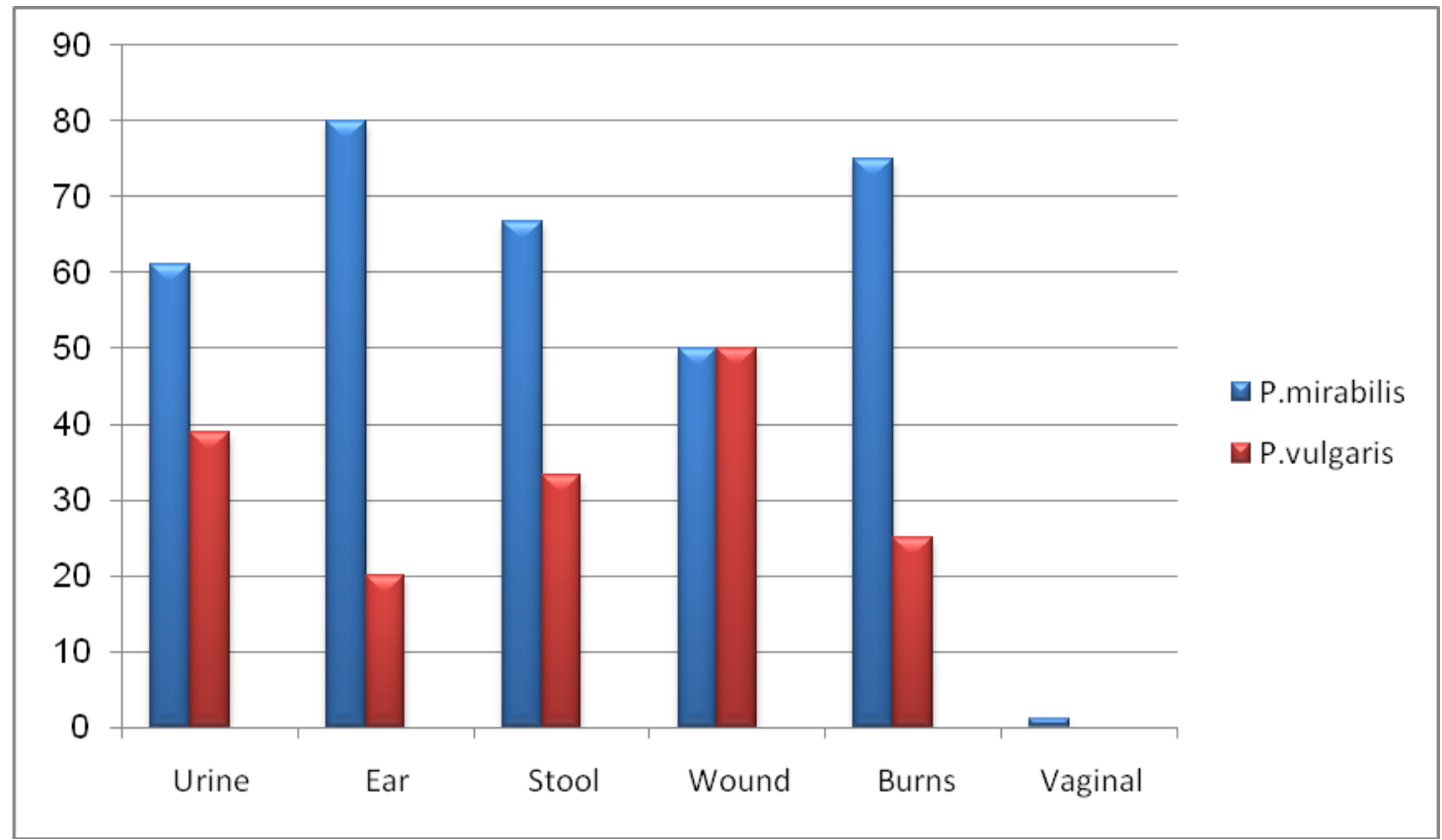


Fig.3a gel electrophoresis of 16 seRNA result

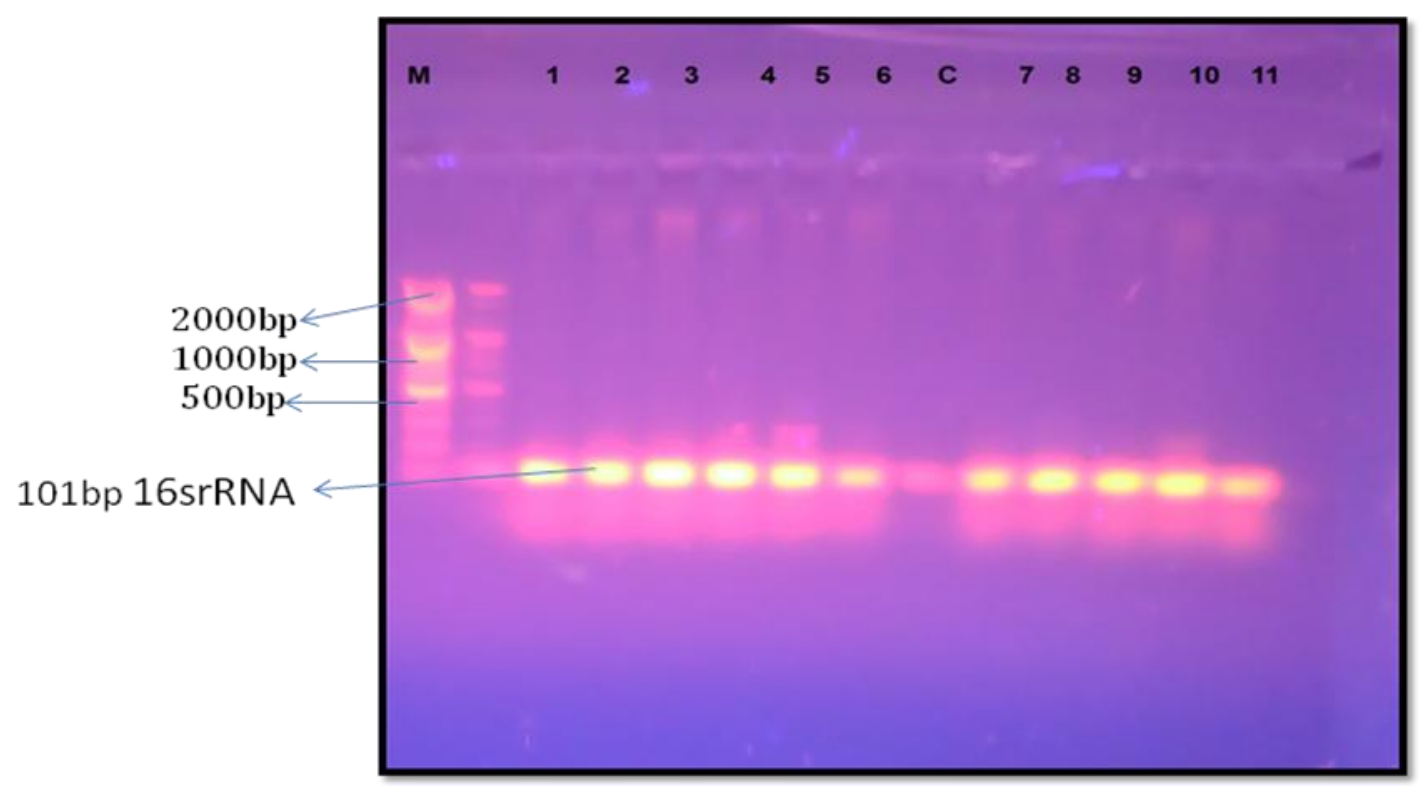

Line (1-11) positive band represents the isolates

M: Ladder with 1500bp

C: Negative control

Fig.3b gel electrophoresis of ureR result

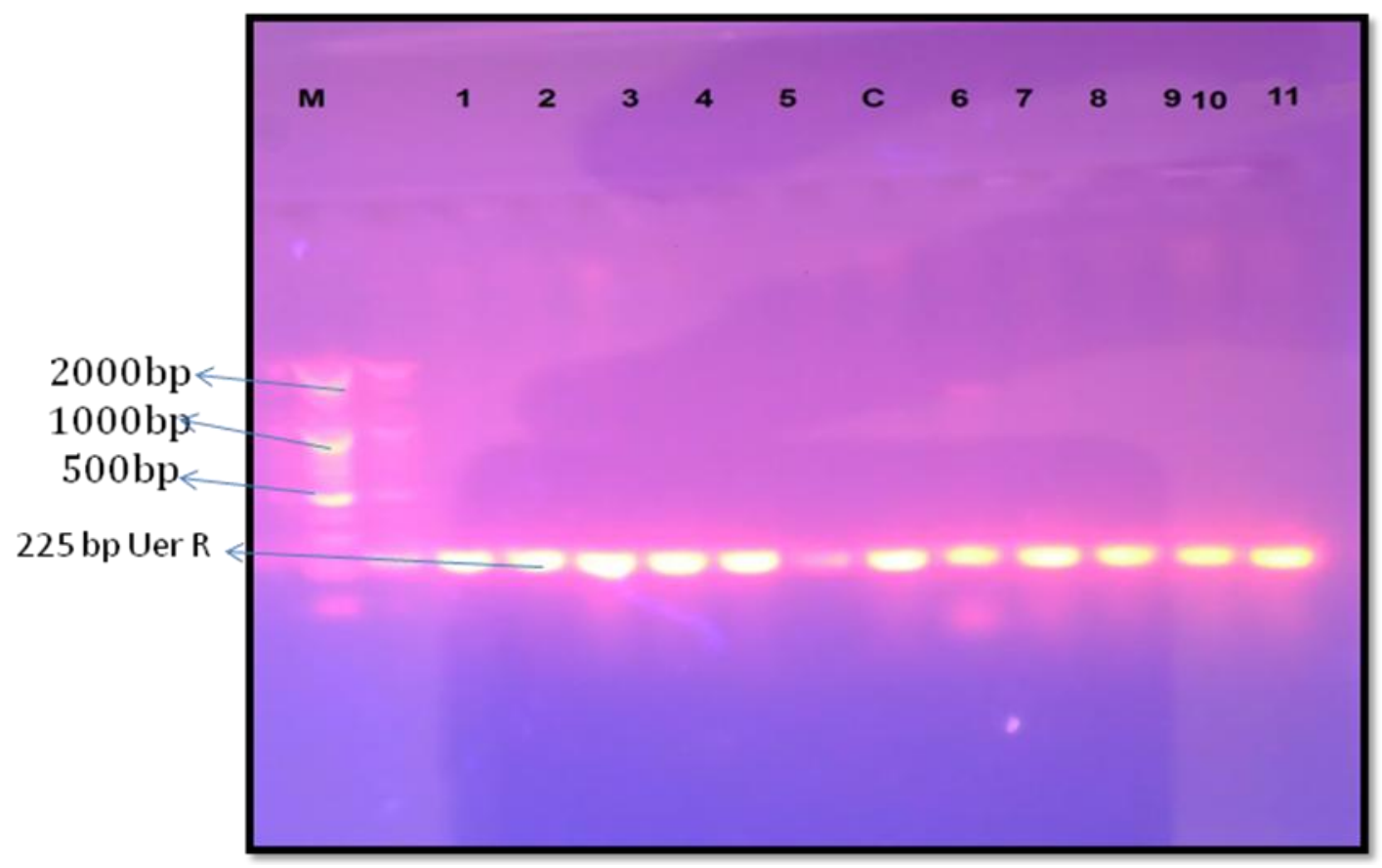

Line (1-11) positive band represents the isolates

M: Ladder with 1500bp.

$\mathrm{C}$ : Negative control 
Fig.4 Susceptibility of Proteus spp isolates to antibiotics

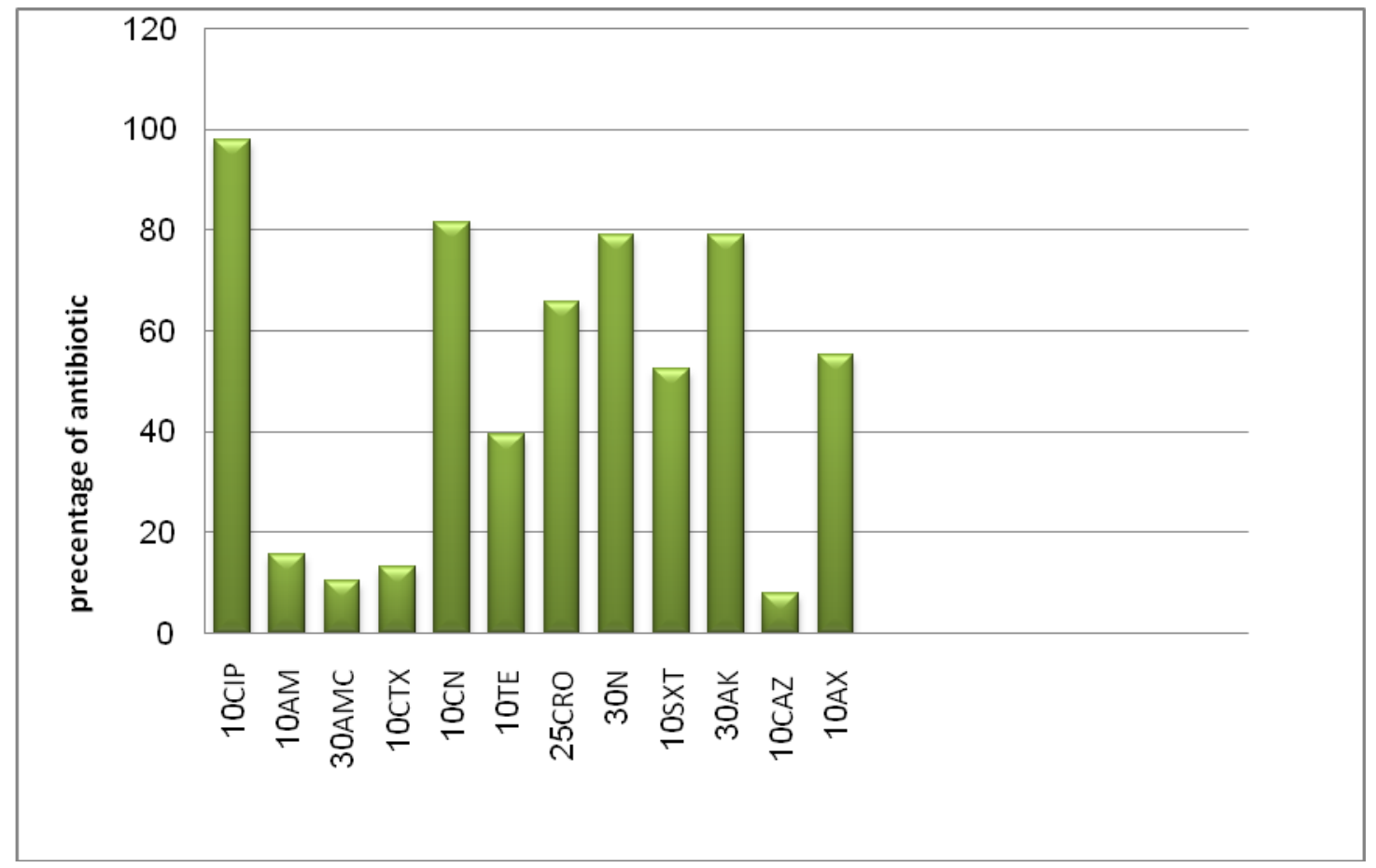

\section{Molecular detection of virulence genes}

The results of PCR amplification to specific 16 srRNA primers indicated that $11(100 \%)$ of Proteus mirabilis isolates gave positive result at $101 \mathrm{bp}$ when compared with allelic ladder,

This result agreed with AI-Dawah (2015). They reported that PCR product was visible of $16 \operatorname{srRNA}$ gene was $(100 \%)$ respectively (Figure 3 ).

The results of PCR amplification to specific ureR primers indicated that $11(100 \%)$ of Proteus mirabilis isolates gave positive result at $225 \mathrm{bp}$ when compared with allelic ladder,

This result agreed with AI-Dawah (2015) and Adnan et al., (2014). They reported that PCR product was visible of $u r e R$ gene was (100\%) respectively. So the ureR gene is responsible for producing urease enzyme in a $(100 \%)$ rate (Figure 3).

\section{Sensitive antibiotic test}

The susceptibility of 38 P. mirabilis isolates to 12 antibiotics (Ampicillin, Amoxicillin, Amikacin, Cefotaxime, Ceftazidime, Cefixime, Ciprofloxacin, Ceftrixon, Nalidixic acid, Tetracycline, Gentamicin, Co- trimoxazol) was investigated by using Kirby-Bauer method. Table (4) and Figure-6 indicated that Poteus spp isolates had variable degrees of Sensitive towards different Antibiotics.

From the above results, it can be noticed that Proteus spp isolates had moderate to low resistant to antibiotics, that inhibit protein synthesis, such as aminoglycosides (Amikacin, gentamycin), Nalidixic acid, and chloramphenicaol, while all isolates showed resistance to Ciprofloxacin, This results agreed with Mordi and Momoh (2009) who found the resistance to Ciprofloxacin was (0\%).

In addition isolates Proteus spp showed moderate to high resistance against antibiotics that inhibited the synthesis of cell wall such as ampencillin, ceftazidime and cefotaxim, amoxicillin+clavulanic acid. This was confirmed by the results of Bahashwan and Shafey (2013) hat found a high susceptibility of Ceftazidime and ampencillin in different isolates of Proteus spp and moderate to high resistant to some types of first generations of cephlaosporins.

Moreover, the results indicated that the resistance of Proteus spp to some antibiotics is increased with prescription of years, because of the wrong and random use of these antibiotics and increasing the rate of Proteus 
infections. On the other hand, this bacteria had ability to produce $\beta$-lactamases, especially extended spectrum $\beta$ lactamases (ESBLs), as well as, their ability to transfer genetic elements carrying the genes of these enzymes, and number of mutations occur with these type of enzymes leading to increase resistance to antibiotic especially $\beta$-lactam, in addition to other mechanisms such as alteration the target site or alteration the access to the target site by modification of penicillin binding proteins (PBPs) (Rossolini et al., 2008; Cantón et al., 2012)

\section{References}

Mordi, R. M. and Momoh, M. I. 2009. Incidence of Proteus species in wound infections and their sensitivity pattern in the University of Benin Teaching Hospital. Afr. J. Biotechnol., 8(5): 725-730.

Betty, A. F, Sahm, D. F. and Weissfeld, A. S. 2007. Bailey and Scott`s Diagnostic microbiology. 12th.ed. Mosby, Inc., an affilinate of Elsevier Inc.

Brooks, G. F, Carroll, K. C., Butel, J. S. and Morse S. A. 2004. Jawetz, Melnick and adelberg`s Medical Microbiology. $24^{\text {th }}$ edn. McGraw Hill companies, London.

Ro`zalski, A., Sidorczyk Z., and Kotelko A. 1997. Potential virulence factors of Proteus Bacilli. Microbiology Mol. Biol. Rev., 61(1): 65-89.

Guentzel M.N. 1996. Escherichia coli, Klebsiella, Enterobacter, Serratia, Citrobacter, and Proteus. In: Barron's Medical Microbiology, Univ. of Texas Medical Branch at Galveston.

O'hara C. M., Brenner, F. W. and Miller, J. M. 2000. Classification, identification, and clinical significance of Proteus, Providencia, and Morganella. Clinical Microbiol. Rev., 13(4): 534-546.

Wassif, C., Cheek, D. and Belas, A. 1995. Molecular analysis of a metalloprotease from Proteus mirabilis. J. Bacteriol., 177(20): 5790-5798.

Mobley, H.L. and R. P. Hausinger.1989. Molecular characterization. Microbial ureases: significance, regulation, and molecular characterization. Microbiol. Mol. Biol. Rev., 53(1), pp: 85-108.

Jacobsen S.M. and Shirtliff, M. E. 2011. Proteus mirabilis biofilms and catheter-associated urinary tract infections. Landes Bioscience, 2(5): 1-6.

\section{How to cite this article:}

Banaz M. Latif, Salah. S. Zayn Aleabdyn and Ibraheem S. Ahmed. 2017. A Comparative Bacteriological and Molecular Study on Some Virulence Factor of Proteus spp Isolated from Clinical and Environment Specimens. Int.J.Curr.Res.Aca.Rev. 5(5): 26-33. doi: https://doi.org/10.20546/ijcrar.2017.505.005
Coker, C., Poore, C.A., Li, X. and Mobely, H.L. 2000. Pathogenesis of Proteus mirabilis urinary tract infection. J. Microbes Infect., 2 (12): 505- 1497.

Harley, J. P. and Prescott, L. M. 2002. Laboratory exercises in Microbiolgy, 5th. ed. McGraw Hill companies, London.

MacFaddin. 2000. Biochemical tests for identification of medical bacteria. Lippincott Williams and Wilkins, USA.

Naz, S. A. and Rasool, S. A. 2013. Isolation, production and characterization of bacteriocin produced by strains from indigenous environments. Pak. J. Bot., 45(1): 261-267.

Feglo, P.K; S. Y. Gbedema; S. N. A. Quay; Y. Adu-Sarkodie and C. O. Okrah. 2010. Occurrence, species distribution and antibitics resistance of Proteus isolates: A case study at the Komfo Anokye teaching hospital in Ghana. Int. J. Pharma Sci. Res., 1(9): 347-352.

Ahmed ,D.A.(2015) Prevalence of Proteus spp in some hospitals in Baghdad City. Iraqi J. Sci., 56(1): 665-672.

Limanskii A, Minukhin V, Limanskaia O, Pavlenko N, Mishina M, Tsygenenko A (2005) Species-specific detection of Proteus vulgaris and Proteus mirabilis by the polymerase chain reaction. ZhMikrobiol Epidemiol Immunobiol., 3: 33-39.

Zhang, W., Niu, Z. Yin, K. and Liu, P. (2013). Quick identification and quantification of Proteus mirabilis by polymerase chain reaction (PCR) assays. Ann. Microbiol., doi: 10.1007/s13213-012-0520-X

Al-duliami , A. ; Nauman , N. ; Hasan, A. SH. and Al-Azawi, Z. H. ( 2011) Virulence Factors of Proteus mirabilis Isolated From Patients otitis media in baquba and its peripheries, Diyala. J. Med., 1(1): 59-75

Al-Dawah, M.J., Al-Hamadany, A.H., Al-Jarallah, E.M. (2015). Study of some virulance factor of Proteus mirabilis isolated from urinary stones patients. J. Biol. Agri. Health Care, 5(23): 2224-3208.

Adnan ,M., Aziz, I.H., Al-Deresawi, M.S.(2014) Molecular detection of Proteus mirabilis using PCR technique among urinary tract infection patients. Iraqi. J. Biotech., 13(2): 35-47.

Bahashwan, S.A. and Shafey, H. M. (2013) antimicrobial resistance patterns of Proteus isolated from clinical specimens. Eur. Sci. J., 9(27).

Rossolini, G.M., M. M.,'Andrea, D. and Mugnaioli, C. 2008. The spread of CTX-M- type extended spectrum $\beta$ lactamases, J. Clin. Microbial infect., 14(1): 33-41.

Cantón, R., Gonzalez-Alba, J.M. and Galan, J. C. 2012. CTXM enzymes. Origin Diffusion, Frontiers Microbiol., Vol. 3 , 